\section{Nature letter heading for trial}

New York

A LETTER from ten Moscow scientists published on Nature's correspondence pages in December $1981(294,688 ; 1981)$ may be cited as nominal defendant in a prosecution under Article 190/1 of the Russian Republic's criminal code, according to a recent Western visitor to Moscow. During the past two years, the signatories remaining in the Soviet Union (two have been allowed to emigrate) have on several occasions been called into the procurator's offices as "witnesses" against the letter. Formally the case is still pending - but the visitor met separately two of the signatories and members of their families all of whom said that pressure was mounting and they feared that formal proceedings might start soon. The plight of one signatory, Dr I.S. Irlin, is referred to in Correspondence (p.490).

The letter drew attention to the signatories" "hard and humiliating" plight since they had filed applications to emigrate to Israel. "Almost all of us have lost our jobs", they wrote, "and we are denied any possibility of continuing with our scientific research. The doors of scientific institutions, laboratories, seminars, conferences and symposia, editorial offices and publishing houses are shut in our faces. We are being deprived of our scientific degrees . . . We have in fact been thrown out of society, but at the same time are not allowed to leave the Soviet Union."

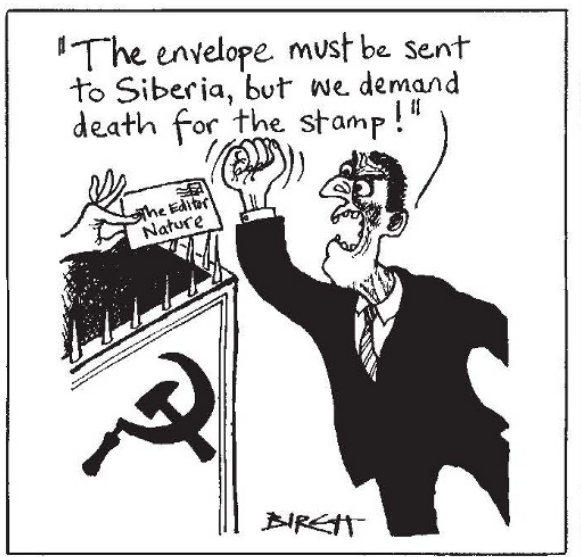

One of several lines adopted by the Soviet interrogators was the legal fiction that the letter might be a forgery. They accordingly demanded that the signatories give evidence on this point. So far, it appears that all have refused either to confirm or deny the authenticity of their signatures.

The rationale behind the odd piece of jurisprudence of accusing the letter itself and not the signatories is simple - in Soviet law, accused persons have the right to stay mute, but witnesses have no such privileges. Already on at least one occasion, the ploy of "prosecuting" a document has been used. Dr Viktor Brailovskii, the mathematician who for many years hosted the unofficial Sunday seminars for refusniks and who has just completed a term of Siberian exile under Article 190/1, was originally called as a witness against the samizdat journal Jews in the USSR, which he edited. During the case new charges were framed against him, and he ended up first in the dock and then in Siberia.

The same ploy may therefore be expected against one or more of the eight remaining signatories (L.A. Dikii, M.I. Freidlin, I.S. Irlin, A.L. Vasilevsky, M.I. Reitman,
S.A. Katz, Ya V. Medvedkov and V.N. Soyfer). The prosecution is clearly keen to get its evidence. The wife of one of the signatories has reported that she has been repeatedly approached by a "friendly" KGB man who urged her that it would be "best" for her husband to testify.

Events seem to follow closely on the trial of Brailovskii. The letter in Nature and the accompanying leading article are well known in the Soviet Union. In the circumstances, it seems strange that news of a possible case touching on editorial policy should reach the editor only through the unofficial channel of a returning academic visitor.

Vera Rich

\title{
Refusnik flow slows to trickle
}

\section{Jerusalem}

DR Yoram Dinstein, rector of Tel Aviv University, last week announced a new endowment fund to establish university posts for Jewish scientists emigrating from the Soviet Union. The timing was somewhat inauspicious. Israeli universities are so short of funds that six months ago it was feared that the entire higher education system might have to close down altogether. Even now, no vacant posts can be filled, and all non-tenured academics are under threat of redundancy. Positive discrimination in favour of new arrivals from the Soviet Union could be a major cause of friction.

The endowment fund has been set up by Mr Fabian Kolker of Baltimore, Maryland, a governor of the university, as part of his overall strategy to halt the problem of the nashrim - Soviet Jews who emigrate on a visa for Israel but who then settle elsewhere, usually in the United States. But the rules of the fund allow the annual interest to be used to help Israeli scientists seeking academic posts should there be no suitable new immigrants from the Soviet Union.

Although Jewish emigration from the Soviet Union is now down to around 50 a month (from a regular 3,500 a month in the early 1970 s and a freak 4,500 a month in 1979), the fund has already been used to create a post for one recent arrival, Dr Grigorii Freiman, a mathematician. But under present circumstances it may be some time before another Soviet candidate arrives.

The clampdown on emigration has focused attention once again on the estimated 300 Soviet Jewish scientists who have already filed visa applications but who have been refused permission to leave. Deprived of their scientific posts, "overqualified" and therefore unemployable in other jobs, refusniks are now liable under new Soviet legislation to arrest for "parasitism" if they are without visible means of support for more than two months.

Since 1964, refusniks have sought to keep up their scientific work through unofficial seminars and even international conferences, the first of which was totally frustrated - the Soviet would-be participants were temporarily deported from Moscow and invited foreign participants denied visas. Last week, an anniversary conference was held at Tel Aviv University (also on the initiative of Mr Kolker), with scientific papers presented by, among others, Professor B. Pippard, Professor E. Segre, Professor P. Kessler, Professor H. Markovich and the Israeli Minister of Science, Professor Yuval Ne'eman. Former refusniks taking part included Professor Benjamin Levich (a Corresponding Member of the Soviet Academy of Sciences), Dr Eytan Finkelstein, Professor Alexander Voronel who founded the refusnik seminars and Professor Mark Nobel, who succeeded him as convener.

A number of papers by present refusniks were read in absentia. The principal aim of such gatherings (including previous conferences in the United States and Stockholm) is to present the refusniks' work in its scientific content and to demonstrate that the seminars (which still continue in Moscow and elsewhere, albeit somewhat less regularly than previously) can generate meaningful work.

The question arises, however, whether such special meetings are the only or the best way of presenting the refusniks' work. Invitations to international conferences abroad are, of course, only symbolic gestures, while conference programmes are now too crowded to permit the custom of the 1960s of keeping blank the time-slot allotted to a Soviet participant who fails to arrive. Even papers sent to be read in absentia will usually be crowded out.

One approach not apparently tried so far is to encourage refusniks to submit contributions for poster sessions. Many of the papers at the Tel Aviv conference were, in fact, of poster length, having been dictated by telephone.

With a scientific colleague abroad as sponsor, such participation could prove a valuable way of keeping the refusniks in the world scientific community. Vera Rich 